\title{
Abstracting About "Abstract Idea"
}

\author{
Jasper L. Tran*
}

\begin{abstract}
An abstract about the abstractness of "abstract idea" is unavoidably too abstract.
\end{abstract}

"The problem is the solution ...."

How to precisely define "abstract idea" in patent law ${ }^{2}$ has long puzzled judges, scholars, and practitioners.3 Frankly, "no one understands what

* Judicial Clerk; Google Policy Fellow. Many thanks to Eric Lindenfeld and Joseph Patton for helpful comments. The usual disclaimer applies.

1. Niklas Luhmann, Operational Closure and Structural Coupling: The Differentiation of the Legal System, 13 CARDOZO L. REV. 1419, 1420 n.3 (1992). Put differently, the solution lies within the problem itself. See, e.g., Peter Biging, Section 1983 Actions by Family Members Based on Deprivation of the Constitutional Right to "Family Association" Resulting from Wrongful Death: Who Has Standing?, 14 FORDHAM URB. L.J. 441, 474 (1985).

2. See, e.g., 35 U.S.C. $\$ 101$ (2012); Alice Corp. Pty. v. CLS Bank Int'l, 134 S. Ct. 2347 , 2355 (2014) ("The 'abstract ideas' category embodies 'the longstanding rule that "[a]n idea of itself is not patentable."” (quoting Gottschalk v. Benson, 4 o9 U.S. 63, 67 (1972))); Bilski v. Kappos, 561 U.S. 593,601 (2010) ("The Court's precedents provide three specific exceptions to $\S 101$ 's broad patent-eligibility principles: 'laws of nature, physical phenomena, and abstract ideas." (quoting Diamond v. Chakrabarty, 447 U.S. 303, 309 (1980))); Le Roy v. Tatham, 55 U.S. (14 How.) $15^{6}, 175\left(185^{2}\right)$ ("A principle, in the abstract, is a fundamental truth; an original cause; a motive; these cannot be patented, as no one can claim in either of them an exclusive right."); see also Mayo Collaborative Servs. v. Prometheus Labs., Inc., 132 S. Ct. 1289 , 1293 (2012); Parker v. Flook, 437 U.S. 584,589 (1978); O'Reilly v. Morse, $5^{6}$ U.S. (15 How.) 62, 112-21 (1854); Neilson v. Harford, Webster's Patent Cases 295, 371 (1841) (English case discussing the same). Dictionary definitions also do not offer much help. Abstract idea, BLACK's LAW DictionaRY 11 (10th ed. 2014) (defining "abstract idea" as "(1847) Intellectual property. [1.] A concept or thought, removed from any tangible embodiment. ... [2.] [O]ne of the categories of unpatentable subject matter, along with natural phenomena and laws of nature. But a process that uses abstract ideas to produce a useful result can be patented. Copyright law likewise will not protect an abstract idea, but only its expression. The law of unfair competition, on the other hand, does protect abstract ideas that meet the other criteria of a trade secret"); see also Merriam-Webster's Collegiate Dictionary 5 (11th ed. 2003) (defining "abstract" as "disassociated from any specific instance ... expressing a quality apart from an object").

3. See, e.g., John M. Golden, Patentable Subject Matter and Institutional Choice, 89 Tex. L. Rev. 1041, 1080, 1080 n.193 (2011); Jeff Kettle, Congress Giveth and Taketh Away: A Look at Section 18 of the America Invents Act and the Review of Business Method Patents, 94 J. PAT. \& TRADEMARK OFF. SOC'Y 201, 207 (2012) ("[G]iven the ambiguities surrounding defining 'abstract ideas,' the court would not broadly use abstractness to find a patent invalid."); Jacob S. Sherkow, The Natural Complexity of Patent Eligibility, 99 IOWA L. REv. 1137, 1152-53, 11 75, 1185-86 
makes an idea 'abstract.'"4

Efforts hitherto have failed because, in short, they have inevitably used either "equally abstract" or "overly narrow" terms.5 Defining "abstract idea" with equally difficult-to-define terms "only perpetuates the problem." ${ }^{6}$ Ergo, the U.S. Supreme Court has repeatedly declined "to delimit the precise contours of the 'abstract ideas' category." 7

Yet "abstract idea" is, by definition, ${ }^{8}$ too abstract for a concrete definition.9 As the Federal Circuit succinctly put: "The problem with articulating a single, universal definition of 'abstract idea' is that it is difficult to fashion a workable definition to be applied to as-yet-unknown cases with as-yet-unknown inventions." 10

Perhaps one could, should, and ought to think more abstractly about

(2014); Maria R. Sinatra, Note, Do Abstract Ideas Have the Need, the Need for Speed?: An Examination of Abstract Ideas After Alice, 84 FORDHAM L. REV. 821, 829-30 (2015) (discussing the ambiguity in defining "abstract idea"); cases cited supra note 2; sources cited infra note 4; see also discussion infra note 11. For empirical analysis on Alice's application by lower courts, see Jasper L. Tran, Two Years After Alice v. CLS Bank, 98 J. PAT. \& Trademark Off. SOC'Y 354, 355-56 (2016); and Jasper L. Tran, Software Patents: A One-Year Review of Alice v. CLS Bank, 97 J. PAT. \& TRADEMARK OFF. SOC'Y 532, 534-35 (2015).

4. Mark A. Lemley et al., Life After Bilski, 63 STAN. L. REV. 1315, 1316 (2011); accord Kristen Osenga, Debugging Software's Schemas, 82 GEO. WASH. L. REV. 1832, 1839-40 (2014) (quoting CLS Bank Int'l v. Alice Corp. Pty., 685 F.3d 1341, 1349 (Fed. Cir. 2012)); Samuel Bragg, Case Note, Patent Law-System Claim Patent-Eligibility After Accenture Global Services, GmbH v. Guidewire Software, Inc., 67 SMU L. REv. 187, 190 (2014) (quoting Accenture Glob. Servs., GmbH v. Guidewire Software, Inc., 728 F.3d 1336, 1348 (Fed. Cir. 2013) (Rader, J., dissenting)).

5. Amdocs (Isr.) Ltd. v. Openet Telecom, Inc., 841 F.3d 1 288, 1294, 1294 n.1 (Fed. Cir. 2016); see also Versata Dev. Grp., Inc. v. SAP Am., Inc., 793 F.3d 13o6, 1331-34 (Fed. Cir. 2015 ), cert. denied, 136 S. Ct. 2510 (2016). Perhaps "abstract idea" defies a single definition.

6. See Robert D. Swanson, Note, Section I I and Computer-Implemented Inventions, 16 STAN. TECH. L. REV. 161, 185 n.108 (2012); see also sources cited supra notes 3-4.

7. Alice, 134 S. Ct. at 2357; see The Supreme Court, 2009 Term-Leading Cases, 124 HARV. L. REV. 370, 376 (2010); see also Bilski, 561 U.S. at 621 (Stevens, J., concurring) ("The Court ... never provides a satisfying account of what constitutes an unpatentable abstract idea."); cases cited supra note 2.

8. See Black's LAW Dictionary, supra note 2; MERriam-WEbster's Collegiate DICTIONARY, supra note 2.

9. See, e.g., Alice, 134 S. Ct. at 2357; Amdocs, 841 F.3d at 1294 ; Versata, 793 F.3d at 1331 ("The third exception-abstract ideas-is more of a problem, a problem inherent in the search for a definition of an 'abstract idea' that is not itself abstract."); $c f$. YUKIO MISHIMA, SUN AND STEEL 9 (John Bester trans., 1970) ("Words are a medium that reduces reality to abstraction for transmission to our reason ....."). Indeed, "meaning lies with the reader rather than the writer." Frank H. Easterbrook, Legal Interpretation and the Power of the Judiciary, 7 HARV. J.L. \& PUB. POL'Y 87, 93 (1984).

10. Amdocs, 841 F.3d at 1 294; see also JEROME FrANK, LAW AND THE MODERN Mind 1 29, 141 (Transaction Publishers 2009) (1930) ("To do justice, to make any legal system acceptable to society, the abstract preestablished rules have to be adapted and adjusted, the static formulas made alive. ... The judge who does not learn how to manipulate these abstractions will become like that physician, described by [John Stuart] Mill, "who preferred that patients should die by rule rather than live contrary to it."”). 
"abstract idea" to conceptualize, understand, and appreciate what "abstract idea" means. ${ }^{11}$ Put simply, concretizing "abstract idea" necessarily requires abstracting about "abstract idea." ${ }^{2}$ Indeed, "the idea which we abstract [about] . . . will always be abstracted." 13

Or am I being too abstract about "abstract idea"? ${ }^{14}$

Table 1

\begin{tabular}{|l|l|}
\hline Abstract & Idea \\
\hline & \\
& \\
& \\
& \\
\hline
\end{tabular}

Figure 1

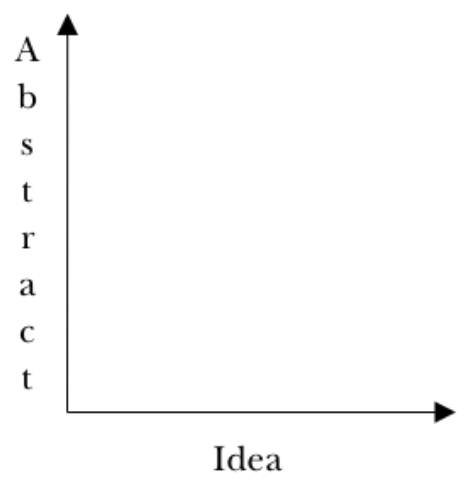

11. Yet "American legal thinkers and actors often display a characteristic disdain for abstraction ....” PIERRE SCHLAG, THE ENCHANTMENT OF REASON 124 (1998); see also Bruce Ackerman, Liberating Abstraction, 59 U. CHI. L. REV. 317, 318-19 (1992) (discussing Justice Scalia's "disdain for abstraction" and Judge Easterbrook's "aversion to abstraction" in constitutional law); Frank H. Easterbrook, Abstraction and Authority, 59 U. CHI. L. REV. 349, 359, 362 (1992) ("Most judges and justices, most of the time, act as if every text contains its own rule for the level of abstraction.... Ronald Dworkin, Owen Fiss, and Harry Wellington, among others, propose putting the abstraction question to the contemporary legal community."). This Catch-22 has unfortunately shackled (most) judges, scholars, and practitioners from understanding "abstract idea."

12. But see Easterbrook, supra note 11, at 380 (positing that, in the constitutional law context, "you can't view abstraction in the abstract"). Put differently, abstracting about "abstract idea" is essentially second-order abstraction, or meta-abstraction.

13. Cleanth Brooks, The Well Wrought Urn: Studies in the Structure of Poetry 205 (1947).

14. Still, how can I be any less abstract about "abstract idea"? See generally JOHN LOCKE, 3 AN ESSAY CONCERNING HumAn UNDERSTANDING (Prometheus Books 1995) (1689) (positing our ability to abstract). But see generally GEORGE BERKELEY, A TREATISE CONCERNING THE PRINCIPLES OF Human KNOWLEDGE (Jonathan Dancy ed., Oxford Univ. Press 1998) (1710) (denying that abstract ideas exist); David Hume, 1 A Treatise of Human Nature (David F. Norton \& Mary J. Norton eds., Clarendon Press 2007) (1738) (similar).

Perhaps some visuals about "abstract idea" might help. See, e.g., tbl. 1; fig. 1 (possibly displaying a graph of table 1); infra p. 63. This is as (un)abstract as it gets-because less is more when it comes to abstraction. See also Sec. \& Exch. Comm'n v. Chenery Corp., 332 U.S. 194, 214 (1947) (Jackson, J., dissenting) ("The more you explain it, the more I don't understand it." (sarcastically quoting Mark Twain)); Martha M. Ertman, For Both Love and Money: Viviana Zelizer's The Purchase of Intimacy, 34 LAW \& SOC. INQUIRY 1017, 1017 (2009) (book review) ("The best academic projects make readers think ...."). Hence, abstract on! 
[This page is intentionally left blank for abstracting about "abstract ideas."] 